\title{
АБИОТИЧЕСКИЕ ФАКТОРЫ, ВЛИЯЮЩИЕ НА СОСТОЯНИЕ ИНТРОДУЦИРОВАННОГО ВИДА ЕЛИ НА ТЕРРИТОРИИ ЕЛИЗОВСКОГО ЛЕСНИЧЕСТВА КАМЧАТСКОГО КРАЯ
}

\section{ABIOTIC FACTORS AFFECTING CONDITION INTRODUCED SPIRIT ON THE TERRITORY OF YELIZOVSKY FORESTRY KAMCHATSKY REGION}

\section{G. Doronina}

Summary. The aim of the study is to determine the influence of abiotic factors on the state of the introduced species of Siberian Spruce (Picea obovata) on the territory of the Elizovsky forestry of the Kamchatka Territory. The article identifies abiotic factors that have a direct impact on the ecological state of the introduced species of Siberian Spruce (Picea obovata) on the territory of the Elizovsky forestry of the Kamchatka Territory. The scientific novelty of the study lies in the development of recommendations for taking into account abiotic factors when carrying out reforestation work on the territory of the Elizovsky forestry of the Kamchatka Territory. As a result, the critical influence of the height of the snow cover on the state of introduced species of Siberian Spruce (Picea obovata) was established.

Keywords: spruce, growth, snow cover, state of the stand, fruiting.

\section{Введение}

B о второй половине 20 века перед лесном хозяйством СССР ставились задачи по повышению качественного состава и продуктивности лесов. Для решение этой задачи особое место отводилось интродукции ценных и быстрорастущих деревьев.

Основываясь на мнении, что лесные культуры древесных экзотов значительно превосходят местные породы по продуктивности, иногда превышая запасы наиболее продуктивных местных пород даже в северных и центральных районах страны в 1,5-2 раза [1, с. 3], на всей территории страны вводились в лесные культуры интродуценты различных древесных пород. На территорию Камчатского края (Камчатской области) в различные годы были интродуцированны следующие древесные породы: сосна, ель сибирская, ель колючая (голубая), сосна кедровая (корейская). Однако, в связи с неоднократным реформированием структуры органов лесного хозяйства в Российской Федерации, в том числе и на территории Камчатского края, оценка эко-
Доронина Галина Сергеевна

Аспирант, Камчатский государственный технический университет, г. Петропавловск-

Камчатский

galserdor@gmail.com

Аннотация. Цель исследования — определить влияния абиотических факторов на состояние интродуцированного вида Ели Сибирской (Picea obovata) на территории Елизовского лесничества Камчатского края. В статье выявлены абиатические факторы, оказывающие непосредственное влияние на экологическое состояние интродуцированного вида Ели Сибирской (Рісеа obovata) на территории Елизовского лесничества Камчатского края. Научная новизна исследования заключается в разработке рекомендаций по учету абиотических факторов при проведении лесовосстановительных работ на территории Елизовского лесничества Камчатского края. В результате установлено критическое влияние высоты снежного покрова на состояние интродуцентов Ели Сибирской (Picea obovata).

Ключевые слова: ель, прирост, снежный покров, состояние древостоя, плодоношение.

логического состояния интродуцированных видов на современном этапе ранее на не проводилась. Таким образом тема является актуальной для определения целесообразности проведения интродукции Ели Сибирской (Picea obovata) на территории Камчатского края.

\section{Цель исслеАования}

Определение влияния абиотических факторов на состояние интродуцированного вида Ели Сибирской (Рісеа obovata) на территории Елизовского лесничества Камчатского края.

\section{Объекты и методы исслеАования}

Исследования проводились в период с 2018 по 2020 г. на территории Елизовского лесничества Камчатского края на двух лесных участках площадью по 0, 5 га. Объектом исследования являлись одновозрастные культуры Ели сибирской (Picea obovata), год закладки лесных культур - 1991. Методической основой проведения на- 
Таблица 1. Климатические условия района исследования

\begin{tabular}{|c|c|c|c|}
\hline \multirow[b]{2}{*}{ № $\pi / n$} & \multirow[b]{2}{*}{ Климатические условия } & \multicolumn{2}{|c|}{ Расчетные величины } \\
\hline & & $\begin{array}{l}2 \text { пробная } \\
\text { площадка }\end{array}$ & 1 пробная площадка \\
\hline 1 & Район по ветру 25 летней повторяемости & VI & $\mathrm{VI}$ \\
\hline 2 & Нормативное ветровое давление, кПа & 0,73 (VI район) & 0,73 (VI район) \\
\hline 3 & Минимальная температура воздуха, ОС & -32 & -32 \\
\hline 4 & Расчетная температура воздуха наиболее холодной пятидневки, 을 & \begin{tabular}{|l|}
-18 \\
-19 \\
\end{tabular} & $\begin{array}{l}-18 \\
-19 \\
\end{array}$ \\
\hline 5 & Среднегодовая температура воздуха, ${ }^{\circ} \mathrm{C}$ & 1,1 & 1,1 \\
\hline 6 & Высота снежного покрова, макс/средняя, см & $281 / 167$ & $450 / 300$ \\
\hline 7 & Преобладающее направление ветра & C3 & $\mathrm{CB}$ \\
\hline 8 & Расчетная температура самых холодных суток, 들 & $\begin{array}{l}-22 \\
-20\end{array}$ & $\begin{array}{l}-22 \\
-20\end{array}$ \\
\hline 9 & Вес снегового покрова, кПа & 5,6 (VIII район) & 6,7(VIII район) \\
\hline 10 & Сейсмичность района, баллы & 9 & 9 \\
\hline 11 & С Максимальный порыв ветра, м/с & 35 & 40 \\
\hline 12 & Радиационный фон, мкР/час & 12 & 10 \\
\hline
\end{tabular}

учно- исследовательских работ являлась «Методология исследований лесных экосистем» [3].

\section{Результаты исслеАования и их обсужАение}

В ходе проведения исследования были заложены две пробные площади: в выделе 6 квартала 20 Южного участкового лесничества и в выделе 19 кв 28 Петропавловского участкового лесничества Елизовского лесничества. Лесные культуры были созданы в 1991 способом посадки 2 летних сеянцев. В ходе проведения оценки экологического состояния данных лесных культур было установлено, что деревья на второй пробной площади вступили в фазу плодоношения. Наличие шишек или плодов свидетельствует о вступлении отдельных деревьев или всего древостоя в возраст репродукции, о достижении ими физиологической зрелости. На первой пробной площади деревья находятся в угнетенном состоянии, высота ствола достигают максимальной высоты не более 80 см, отмечена многовершинность, 70\% деревьев приобретают стланиковую форму. Возникает необходимость определить, какие именно факторы оказывают негативное воздействие на древостои и учитывать их при проведении лесовосстановительных работ в дальнейшем. Были рассмотрены следующие абиотические факторы.

По схеме физико-географического районирования Севера Дальнего Востока район исследования находится в южной части складчато-вулканической тундрово-лесной области Восточной Камчатки, в северной части Южного вулканического нагорья полуострова Камчатка, на восточной окраине Охотской континентальной плиты в 220 км к северо-западу от Курило-Камчатского желоба, по которому проводится граница континентальной плиты с погружающейся под неё Тихоокеанской плитой. По данным зоне субдукции плит соответствует сейсмофокальная зона, погружающаяся под континентальную плиту под углом $57^{\circ}$.

Климат района исследования находиться под влиянием Тихого океана и Охотского моря, для которого характерна активная циклоническая деятельность. По схеме климатического районирования Камчатки район исследования располагается в климатическом районе Авачинской низменности, которая входит в состав Восточной приморской подобласти. Климат района строительства насосной станции морской, влажный, с умеренно холодной, снежной, продолжительной (ноябрь-апрель) зимой и коротким (июль-сентябрь), умеренно теплым, влажным, дождливым летом.

Среднегодовая температура воздуха плюс $1,1^{\circ} \mathrm{C}$. Самый холодный месяц в году январь со среднемесячной температурой минус $10,5^{\circ} \mathrm{C}$. Наиболее теплым месяцем является август со среднемесячной температурой плюс $13,2{ }^{\circ} \mathrm{C}$. Экстремальные значения температуры установлены в 1959 г.: абсолютный минимум минус $32{ }^{\circ} \mathrm{C}$, абсолютный максимум - плюс $32^{\circ} \mathrm{C}$. Устойчивые морозы наступают во второй декаде ноября и сохраняются до начала апреля. Средняя продолжительность безморозного периода 190 дней. Средняя продолжительность отопительного периода (периода со среднесуточной температурой воздуха ниже плюс $\left.8{ }^{\circ} \mathrm{C}\right)-257$ дней. Глубина промерзания грунта под снегом не превышает 50 см, а на оголенных поверхностях колеблется от 133- 
162 см на глинистых грунтах до 174-197 см на песках и крупнообломочных грунтах.

Среднегодовое количество осадков 900 мм/год, в т.ч. около 55\% в виде дождя. Снежный покров начинает формироваться во второй половине октября. Средняя многолетняя дата образования устойчивого снежного покрова - 1 ноября, а схода - 13 мая. Продолжительность залегания снежного покрова 174-194 дня. Наибольший рост высоты снежного покрова происходит в декабре-январе, а в конце марта - первой половине апреля он достигает максимальной высоты. Средняя высота снежного покрова 167 см, а максимальная в районе п. Паратунка 281 см. К концу мая снег полностью тает.

В течение года, особенно зимой преобладают ветры западного и юго-западного направлений (49\%) и только летом чаще бывают ветры восточных румбов. Среднегодовая скорость ветра 1,9 м/с. Среднее среднегодовое число дней с сильным ветром (более $15 \mathrm{~m} / \mathrm{c}$ ) составляет 17,9 дня, а максимальное - 50 дней. Максимальные порывы ветра достигают $35 \mathrm{~m} / \mathrm{c}$.

В году в среднем бывает: 5-11 дней с метелями, 20-33 дня с туманами, 2 дня с гололедом, 14-41 день с изморо- зью, 14-42 дня с обледенением всех видов, 2 дня с грозами, до 2 дней с градом.

К опасным явлениям погоды относятся: ураганные ветры, аномально-холодная погода, очень сильные осадки, сильные и продолжительные метели.

В природных ландшафтах района исследования развиты вулканогенные охристые супесчаные почвы (мощностью 0,3 м), на которых произрастают каменноберезовые леса. Состав почвенного покрова одинаковый для обоих пробных площадей.

Климатические данные приведены в таблице.

\section{Эак^ючение}

В ходе проведенного исследования можно сделать вывод, что на экологическое состояние интродуцированного вида Ели сибирской на территории Елизовского лесничества Камчатского края определяющее значение имеет высота снежного покрова как главный абиотический фактор. При дальнейшем выборе площадей лесовосстановления под посадки елей необходимо учитывать высоту снежного покрова.

\section{ЛИТЕРАТУРА}

1. Лапин П. И., Калуцкий К. К., Калуцкая О. Н. Интродукция лесных пород.- М.: Лесн. пром-сть, 1979. — 224 с.

2. Книга учета лесных культур на территории Елизовского мехлесхоза Камчатского управление лесами, 1980-1995 г.

3. Методология исследований лесных экосистем: Методическое пособие/Сост. Е. Н. Пилипко. — Вологда-Молочное: ИЦ ВГМХА, 2013. — 103 с. 